\title{
SAMA president, medicopolitical veteran, psychiatrist and treatment pioneer
}

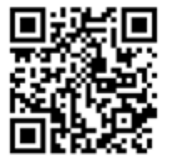

Keeping a cool head and listening and communicating while being 'relevant and realistic' is what the new President of the South African Medical Association (SAMA), top psychiatrist Prof. Denise White, a 12-year veteran of SAMA leadership, hopes to bring to her executive and council.

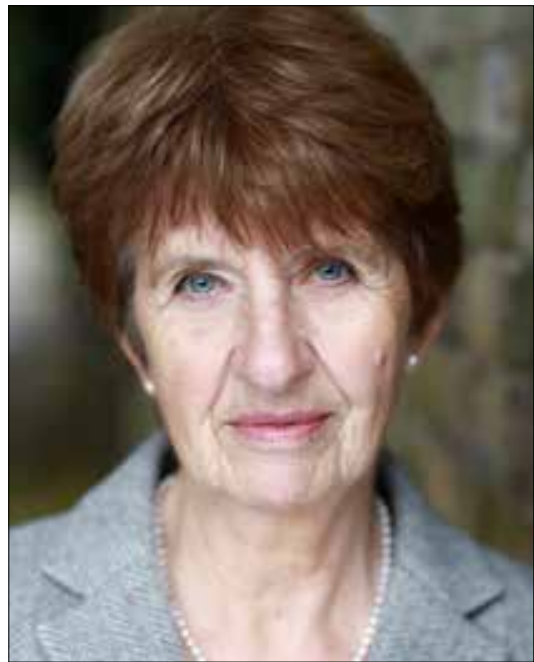

Prof. Denise White, new President of the South African Medical Association.

Battle-hardened in the trenches of the unprecedented June 2009 doctor strike (while acting as SAMA chairperson) and a pivotal negotiator for huge improvements in doctors' salary packages via changes to commuted overtime a decade earlier (as chairperson of SAMA's public sector committee), White, now 70 , is both 'honoured' and ready for a more ceremonial role. Her calm composure and steady hand in the face of thousands of angry, striking young public sector doctors, outraged by two years of government heel-dragging in implementing the occupation-specific dispensation (OSD) and at odds with SAMA over tactics to bring about change, won her widespread respect among both medical friends and foes. What was a short-lived but highly effective revolution (striking doctors kept one step ahead of their employers by networking via Facebook to orchestrate wildcat nationwide unprotected strikes, at one stage even commandeering SAMA's
HQ to stage a press conference) led to the first decent increases for doctors in decades, with White and the SAMA Exco subsequently championing the defence and job reinstatement of hundreds of young physicians.

White changed an aspect of global psychiatric practice, receiving international recognition early in her career when she and a colleague identified a link between patients admitted to Groote Schuur's psychiatric wards with catatonic illness and neuroleptic malignant syndrome (NMS), with an associated $20 \%$ mortality rate. By probing why some patients developed NMS and others not, they identified the administration of neuroleptic drugs to patients with a catatonic illness as the major culprit. When the international scientific and cultural embargoes were lifted on apartheid South Africa (SA), she immediately became a highly sought-after speaker at international psychiatric conferences.

White was described as 'an inspirational negotiator, a quiet and dedicated leader and a clinician of immense skill and intuition' on receiving this year's South African Society of Psychiatrists Distinguished Service Award. As to her willingness to accept the appointment as President of SAMA, White says 'I think I can add some value. Obviously I am very humbled being elected as President. It is a ceremonial, titular role, and I think I have an advantage in having had "hands-on" experience with the function and dynamics of the organisation as a member of its Exco in the past. As vice-chair I sat next to five or six different presidents. I won't be in the front line politically, but hopefully I will be able to offer some insight into processes that won't be unfamiliar to me.'

Two years before leaving the SAMA leadership cadre in 2009, White was appointed to the Medical and Dental Professions Board (MDB), where she served two 5-year terms and was appointed to several subcommittees of the Board dealing with matters of professional conduct, as well as serving on the health committee of Council (assessing and ruling on 'impaired' practitioners), tasks she says she found 'very worthwhile?
'It felt like I was really making a contribution to the profession as a whole. As a Board member our mandate was largely non-political and carried out strictly within the legislative framework governing the operations of the HPCSA [Health Professions Council of South Africa],' she added. Asked her opinion on the ministerial probe led by her UCT colleague, cardiologist Prof. Bongani Mayosi into dysfunction in the statutory HPCSA, under which the MDB (one of 12 professional boards) falls, she had this to say: 'The most pertinent issue is that any recommendations they make are put into effect. The report must not just gather dust.' SAMA has a strained relationship with the HPCSA, given that the MDB pays the lion's share of its costs but suffers vastly diluted bargaining power. There are longstanding calls by SAMA for the MDB to step outside the HPCSA and form its own council (like the nurses and pharmacists), giving it far more autonomy and individual voice. Of the HPCSA dysfunction probe, White said that with many 'critical, experienced' people having left the Council (shaken by administrative fraud scandals and charges of not carrying out its statutory duties), a great deal of institutional memory had been lost - when the entire structure was dependent on efficient and effective administration.

\section{White changed an aspect of global psychiatric practice, receiving international recognition early in her career when she and $a$ colleague identified a link between patients admitted to Groote Schuur's psychiatric wards with catatonic illness and neuroleptic malignant syndrome, with an associated $20 \%$ mortality rate.}

Asked what lessons she had learnt and could use in her counsel of the SAMA executive, White replied: 'Communication is hugely important. To listen and communicate around issues and to be realistic and 
relevant in dealing with matters. To keep channels of communication open with various stakeholders is essential. SAMA is a collective - teamwork is necessary in brainstorming and decision-making. We have to put personal issues aside for the greater good of health in SA. SAMA is a critical role-player and we have to stay internally intact as a team when big matters such as National Health Insurance are discussed.' She said that the organisation was challenged by the fine line it has to tread between politics and professional issues, as well as the need to keep its ear to the ground' to ensure that it was fulfilling its mandate for members. 'The challenge is being effective for very disparate groups To be a trade union and to represent the interests of both public and private sector doctors. It's not an easy task. This is not an organisation where you can step up to any leadership position being timid or naive you have to don an asbestos shield to deflect the heat of a crisis and remain cool'. She said she was fortunate no longer to be in the day-to-day political decision-making engine room, and hoped she could be 'that person who can add a perspective in times of crisis or decision-making'

Unsurprisingly, White's 'signature theme' during her year-long presidential tenure will be mental health. With the lifetime adult prevalence of common mental disorders in SA standing at $30 \%$, a full $11 \%$ of citizens experiencing substance abuse problems and maternal mental disorders three times higher in low-income areas, her advocacy will be highly valued by coalface organisations. Says White: 'The maternal mental disorder statistic (for one) is totally unacceptable. Again, it appears the country is not focusing on developing its resources. The multiprofessional team is essential for the delivery of good mental health. You need mental health workers out there in the community clinics and rural areas. It can't just be hospital based. We need to work out ways of task shifting, with doctors supervising those who actually do the work. I don't think we've developed an effective and adequate human resources plan - we have the research but what comes of it? Unfortunately mental health is the Cinderella of the healthcare professions always the Oliver Twist.'

Grossly inadequate and unco-ordinated government spending on the treatment of mental illness - which affects one in six South Africans - is costing SA 2.2\% of its annual GDP. ${ }^{[1]}$ It is also failing to reduce the 230 attempted suicides recorded daily, while $48 \%$ of people living with HIV/ AIDS continue to suffer from a mental health condition. ${ }^{[2]}$ Mental health disorders comprise five of the ten leading causes of health disability in SA. According to research published by White's colleagues, UCT head of psychiatry Prof. Dan Stein and his associate Prof. Crick Lund, mental health issues cost the SA economy six times the cost of their treatment. Over the past two decades, a seemingly progressive national policy shift to decentralisation of care has reduced the number of mental hospitals, with no corresponding increase in community-based mental health facilities, leading to $7.7 \%$ fewer beds across all provinces and a downward spiral in delivery. ${ }^{[3]}$

White takes over the SAMA presidency reins from groundbreaking medical educationalist, former Medical Research Council chairperson, advisor on upgrading academic hospitals and Eastern Cape healthcare planning commissioner Prof. Lizo Mazwai.

\section{Chris Bateman \\ chrisb@hmpg.co.za}

S Afr Med J 2015;105(12):1003-1004.

DOI:10.7196/SAMJ.2015.v105i12.10301

1. Lund C, Myer L, Stein D, Williams DR, Flisher AJ. Mental illness and lost income among adult South Africans. Soc Psychiatry Psychiatr Epidemiol 2013;48(5):845-851. [http://dx.doi. org/10.1007/s00127-012-0587-5

2. Lund C, Kleintjes S, Kakuma R, Flisher AJ, the MHaPP Research Programme Consortium. Public sector mental health systems in South Africa: Inter-provincial comparisons and policy implications. Soc Psychiatry Psychiatr Epidemiol 2010;45(3):393- 404. [http://dx.doi.org/10.1007/s 00127-0090078-5]

3. Lund C, de Silva M, Plagerson S, et al. Poverty and mental disorders: Breaking the cycle in low and middle income countries. Lancet 2011:378(9801):1502-1514. [http//dx doi. org/10.1016/S0140-6736(11)60754-X] 